\title{
STANDAR NASIONAL PERHITUNGAN BATAS PENDAPATAN MBR (STUDI KASUS KOTA BANDUNG)
}

\author{
National Standard Calculation Standards For MBR Income \\ (Case Study Of Bandung City)
}

\author{
Yulinda Rosa dan Sri Sulasmi \\ Pusat Litbang Permukiman Badan Litbang PU \\ Jl. Panyaungan, Cileunyi Wetan, Kabupaten Bandung \\ E-mail: yulindarosa@gmail.com
}

\begin{abstract}
Abstrak
Standar batas penghasilan MBR yang mengakomodir kemampuan daya beli sangat diperlukan berkaitan dengan penyediaan rumah bagi MBR. Biaya perumahan ditentukan berdasarkan program subsidi pemerintah. Harga rumah tapak FLPP berdasarkan Keputusan Menteri Pekerjaan Umum dan Perumahan Rakyat No. 552 Tahun 2016 untuk Provinsi Jawa Barat sebesar Rp 130.000.000 dan harga rumah susun FLPP berdasarkan sebesar Rp 262.800.000,. Peraturan Menteri Pekerjaan Umum dan Perumahan Rakyat No. 10 tahun 2019 sudah keluar, karena data primer yang digunakan tahun 2017, maka aturan yang digunakan juga disesuaikan dengan aturan yang berlaku pada tahun yang sama. Besaran angsuran merupakan fungsi dari harga jual rumah yang dibagi berdasarkan cakupan wilayah propinsi. Variasi harga tersebut tidak sesuai dengan variasi daya beli masyarakat terhadap kebutuhan pokok pangan dan sandang yang jauh lebih bervariasi sesuai dengan kota/kabupaten, kondisi tersebut akan menimbulkan permasalahan ketika penerapan di lapangan. Angka yang paling sesuai untuk menggambarkan variasi daya beli masyarakat adalah angka Kebutuhan Hidup Layak (KHL), dijadikan sebagai dasar dalam penentuan Upah Minimum Kota/Kabupaten. Kelebihan dari batas pendapatan MBR berdasarkan KHL adalah lebih sensetif terhadap perubahan kemampuan daya beli masyarakat, karena angka tersebut dikorelasikan dengan angka KHL dan UMK, akan lebih menggambarkan kondisi ril di lapangan dimana harga rumah dalam satu propinsi pada kenyataanya cukup bervariasi untuk setiap kota/kabupaten. Harga rumah yang berdasarkan Keputusan Menteri Pekerjaan Umum dan Perumahan Rakyat No. 247 tahun 2015 tentang Proporsi Pendanaan Kredit Pembiayaan Pemilikan Rumah Sejahtera dibagi berdasarkan cakupan wilayah propinsi.
\end{abstract}

Kata Kunci: standar nasional, batas pendapatan, Masyarakat Berpenghasilan Rendah (MBR), kota Bandung.

\begin{abstract}
The MBR income limit standard that accommodates purchasing power is very much needed in relation to providing housing for the MBR. Housing costs are determined based on government subsidy programs. FLPP site prices are based on Minister of Public Works and Public Housing No. Decree. 552 of 2016 for the Province of West Java in the amount of Rp. 130,000,000 and the price of FLPP flats based on Rp. 262,800,000. Minister of Public Works and Public Housing Regulation No. 10 of 2019 has come out because, the primary data used in 2017, the rules used are also adjusted to the rules that apply in the same year. The installment amount is a function of the selling price of the house which is divided based on the province's area. The price variation is not in accordance with the variation in people's purchasing power of basic food and clothing needs that are far more varied according to the city/district, these conditions will cause problems when applied in the field. The most appropriate figure to describe variations in people's purchasing power is the Decent Living Needs (KHL) rate, which is used as the basis for determining City / District Minimum Wages. The advantage of the MBR income limit based on the KHL is that it is more sensitive to changes in people's purchasing power, because that number is correlated with the KHL and MSE figures, which will better reflect real conditions in the field where housing prices in one province are in fact quite varied for each city/district. House prices are based on the Decree of the Minister of Public Works and Public Housing No. 247 of 2015 concerning Proportion of Funding for Financing of Housing for Prosperous Houses Loans divided by provincial area coverage.
\end{abstract}

Keywords: national standards, income limits, Low-Income Communities (MBR), Bandung city.

\section{PENDAHULUAN}

MBR adalah masyarakat yang mempunyai keterbatasan daya beli. Pengertian daya beli adalah kemampuan konsumen membeli banyaknya jumlah barang yang diminta pada suatu pasar tertentu, pada tingkat pendapatan tertentu dan dalam periode tertentu, Putong (2003). Besarnya daya beli suatu keluarga sangat tergantung pada pendapatan atau upah. Upah adalah hak pekerja/buruh yang diterima dan dinyatakan dalam bentuk uang sebagai imbalan dari pengusaha atau pemberi kerja kepada 
pekerja/buruh yang ditetapkan dan dibayarkan menurut suatu perjanjian kerja, kesepakatan, atau peraturan perundang-undangan, termasuk tunjangan bagi pekerja/buruh dan keluarganya atas suatu pekerjaan dan/atau jasa yang telah atau akan dilakukan (Peraturan Pemerintah Republik Idonesia Nomor 78 tahun 2015). Formulasi upah dilakukan secara tripartit antara pengusaha, pemerintah dan serikat buruh untuk mencapai kesepakatan akan tingkat upah yang adil bagi semua pihak, terutama adil buat buruh. Formulasi kebijakan pengupahan dirumuskan tingkat upah yang menjadi dasar pengupahan setiap daerah, sehingga besaran tingkat upah masing-masing daerah kabupaten/kota berbeda, disesuaikan berdasarkan kemampuan ekonomi makro setiap daerah (Warcito, 2016).

Perlu adanya standar untuk menentukan batas penghasilan MBR yang mengakomodir kemampuan daya beli. Biaya perumahan ditentukan berdasarkan program subsidi pemerintah. Harga rumah tapak FLPP berdasarkan Keputusan Menteri Pekerjaan Umum dan Perumahan Rakyat No. 552 Tahun 2016 untuk Provinsi Jawa Barat sebesar Rp 130.000.000 dan harga rumah susun FLPP berdasarkan sebesar $\mathrm{Rp}$ 262.800.000,-. Peraturan Menteri Pekerjaan Umum dan Perumahan Rakyat No. 10 tahun 2019 sudah keluar, karena data primer yang digunakan tahun 2017, maka aturan yang digunakan juga disesuaikan dengan aturan yang berlaku pada tahun yang sama. Berdasar hasil simulasi pada skenario dasar model penyediaan dan pembiayaan perumahan bagi MBR, penghasilan minimal MBR yang mampu mengakses KPR FLPP saat ini adalah Rp3.850.000 per bulan. MBR yang berpenghasilan kurang dari itu tidak akan mampu. Sedangkan jika dilihat dari struktur penghasilan MBR di Indonesia, lebih dari $60 \%$ penduduk berpenghasilan di bawah angka tersebut (Puskim, 2016). Hasil taksiran secara umum mengindikasikan, di Kota Jayapura nilai indeks keterjangkauan penghasilan MBR terhadap rumah FLPP tergolong "Sangat tidak terjangkau" bagi mayoritas kelompok MBR dengan median penghasilan setara UMR dan "Hampir tidak terjangkau" untuk minoritas kelompok MBR dengan batas penghasilan mendekati maksimal (4 juta/bln). Di Kota Manado, nilai indeks keterjangkauan MBR terhadap rumah FLPP tergolong "Hampir tidak Terjangkau" bagi kelompok mayoritas dan "Terjangkau" bagi kelompok minoritas MBR (Setiadi, 2018).

Besaran angsuran merupakan fungsi dari harga jual rumah yang dibagi berdasarkan cakupan wilayah propinsi. Variasi harga tersebut tidak sesuai dengan variasi daya beli masyarakat terhadap kebutuhan pokok pangan dan sandang yang jauh lebih bervariasi sesuai dengan kota/kabupaten, kondisi tersebut akan menimbulkan permasalahan ketika penerapan di lapangan. Angka yang paling seuai untuk menggambarkan variasi daya beli masyarakat adalah angka Kebutuhan Hidup Layak (KHL), angka tersebut menjadi dasar dalam penentuan Upah Minimum Kota/Kabupaten.

Upah minimum adalah upah bulanan terendah yang terdiri atas:

a. Upah tanpa tunjangan; atau

b. Upah pokok termasuk tunjangan tetap.

hanya berlaku bagi pekerja/buruh dengan masa kerja kurang dari 1 (satu) tahun pada Perusahaan yang bersangkutan. Sementara upah bagi pekerja/buruh dengan masa kerja 1 (satu) tahun atau lebih dirundingkan secara bipartit antara pekerja/buruh dengan pengusaha di perusahaan yang bersangkutan. Upah Minimum Kabupaten/Kota adalah Upah Minimum yang berlaku di Daerah Kabupaten/Kota. Penetapan Upah minimum kabupaten.kota dilakukan oleh Gubernur. Tujuan utama dari upah minimum adalah meningkatkan kesejahteraan pekerja.

Hak pemenuhan hidup sejahtera sesuai dengan UUD 45 pasal $28 \mathrm{H}$ ayat 1 yang harus dicapai dengan terpenuhinya kebutuhan pangan, sandang dan papan secara layak, khususnya bagi masyarakat berpenghasilan Rendah (MBR), mempunyai hak untuk mendapatkan perumahan, sehingga perlu mendapat dukungan pemerintah untuk memperoleh rumah, dan merupakan kewajiban pemerintah memenuhi kebutuhan rumah bagi MBR. Kemudahan dan/dan atau bantuan pembangunan dan perolehan rumah bagi MBR dapat berupa: subsidi perolehan rumah, stimulan rumah swadaya, insentif perpajakan, perijinan, asuransi dan penjaminan, penyediaan tanah, dan atau prasarana, sarana, dan utilitas umum UU nomor 1 tahun 2011).

Selain itu, keterkaitan standar kehidupan layak dengan masyarakat berpenghasilan rendah (MBR), sudah sering digunakan, khususnya beberapa regulasi seperti: Undang-undang nomor 1, tahun 2011, tentang Perumahan dan Kawasan Permukiman; Permenpera nomor 5, tahun 2007 tentang Pengadaan Perumahan dan Permukiman dengan dukungan fasilitas subsidi perumahan; Permenpera nomor 1, tahun 2014, tentang Petunjuk Teknis Penggunaan Dana Alokasi Bidang Perumahan dan Kawasan Permukiman; Permenpera nomor 4, tahun 2014 tentang Petunjuk Pelaksanaan Fasilitas Likuiditas Pembiayaan Perumahan dalam rangka Pengadaan Perumahan Melalui Pembiayaan 
Pemilikan Rumah Sejahtera dan lain sebagainya. Dari urain di atas dapat dilihat bahwa istilah MBR, sudah dijadikan kriteria beberapa program pemerintah untuk bantuan masyarakat, namun sampai saat ini masih menjadi pembicaraan, seperti apa batasn, dasar dan kriteria MBR. Dalam tulisan ini akan di bahas mengenai rumusan umum MBR berdasarkan sumber data sekunder, dari BPS (garis kemiskinan) dan Kemenakertrans (kebutuhan hidup layak), merupakan salah satu dasar untuk penentuan MBR pada level terbawah (Rosa, 2018).

Uraian di atas memberikan gambaran bahwa standar penghasilan MBR dikaitkan dengan pemenuhan kebutuhan rumah layak perlu memperhitungkan terlebih dahulu pemenuhan terhadap pangan dan sandang secara layak. Penentuan angka standar penghasilan MBR dapat dikaitkan dengan angka standar $\mathrm{KHL}$ ditambah dengan pemenuhan kebutuhan rumah dengan berbagai status kepemilkan mulai dari sewa atau milik dengan jenis konstruksi rumah landed atau rumah susun (rusun).

Dalam tulisan ini akan dibahas tata cara perhitungan MBR berdasarkan kemampuan daya beli keluarga MBR untuk memenuhi kebutuhan hidup layak minimal Kebutuhan pokok) pangan, sandang dan papan termasuk pengadaan rumah sebagai tempat tinggal. Dari rata-rata penghasilan MBR di Kecamatan Banyumanik, Kota Semarang menyisihkan $20 \%$ dari rata-rata penghasilan mereka digunakan untuk penyedian rumah baik dengan sewa atau mencicil (Akbar dan Asnawi, 2014). Langkah selanjutnya adalah dilakukan pengklasteran terhadap penghasilan MBR tersebut untuk menyesuaiakan dengan tingkatan seseorang dalam kemampuan memperoleh rumah (sewa atau milik, landed atau rusun).Klastering penghasilan MBR akan mengacu pada penentuan indeks Price Income Ratio (PIR). Angka yang didapat akan dibandingkan dengan batas pendapatan MBR yang telah ditetapkan dalam Peraturan Menteri Pekerjaan Umum dan Perumahan Rakyat Republik Indonesia Nomor 20 tahun 2014.

\section{TINJAUAN PUSTAKA}

\section{a) Kredit Pemilikan Rumah}

Peraturan Menteri Pekerjaan Umum dan Perumahan Rakyat Nomor 20 tahun 2014, menetapkan batas penghasilan rumah tangga MBR dibagi menjadi empat kelompok:

1. Kredit Pemilikan Rumah (KPR) sejahtera tapak adalah kredit dengan dukungan Fasilitas Likuiditas Pembiayaan Perumahan
(FLPP) yang diterbitkan oleh bank pelaksana kepada MBR dalam rangka pemilikan rumah sejahtera tapak yang diberi dari orang perorangan atau badan hukum;

2. KPR sejahtera Syariah tapak adalah pembiayaan berdasarkan prinsip Syariah dengan dukungan FLPP yang diterbitkan oleh bank pelaksana yang beroperasi secara syariah kepada MBR dalam rangka pemilikan rumah sejahtera Syariah tapak yang diberi dari orang perorangan atau badan hukum;

3. Kredit Pemilikan Rumah (KPR) sejahtera rusun adalah kredit dengan dukungan Fasilitas Likuiditas Pembiayaan Perumahan (FLPP) yang diterbitkan oleh bank pelaksana kepada MBR dalam rangka pemilikan satuan rumah sejahtera rusun yang diberi dari orang perorangan atau badan hukum;

4. KPR sejahtera Syariah tapak adalah pembiayaan berdasarkan prinsip Syariah dengan dukungan FLPP yang diterbitkan oleh bank pelaksana yang beroperasi secara syariah kepada MBR dalam rangka pemilikan satuan rumah sejahtera Syariah rusun yang diberi dari orang perorangan atau badan hokum.

Btas pendapatan maksimal MBR untuk poin 1 dan 2 Rp 4.000.000,- serta poin 3 dan 4 Rp 1.000.000,-

b) Kebutuhan Hidup Layak (KHL) dan Garis Kemiskinan (GK)

Kemenakertrans mengeluarkan nilai standar Kebutuhan Hidup Layak (KHL) merupakan batasan standar pengeluaran seorang buruh dengan pengalaman kerja maksimal 1 tahun untuk hidup secara layak dari segi pangan (3.000 kkal), sandang, papan, pendidikan, kesehatan, transportasi, rekreasi dan tabungan (basic needs). Angka KHL bervariasai setiap kota/kabupaten/propinsi dipengaruhi standar harga atau biaya hidup masyarakat, dijadikan acuan penentuan upah minimum kota/ kabupaten/propinsi, sebagai angka dasar dalam menentukan angka upah minimum. Kebutuhan Hidup Layak yang selanjutnya disingkat $\mathrm{KHL}$ adalah standar kebutuhan seorang pekerja/ buruh lajang untuk dapat hidup layak secara fisik dalam 1 bulan. Kebutuhan kalori layak bagi pekerja buruh lajang $3.000 \mathrm{k}$ kalori/org/hari. Standar Komponen dalam KLH:
1. Makanan \& Minuman (11 items)
2. Sandang (13 items)
3. Perumahan (26 items)
4. Pendidikan (2 item)
5. Kesehatan (5 items) 
6. Transportasi (1 item)

7. Rekreasi dan Tabungan (2 item).

Upah minimum adalah upah bulanan terendah berupa upah tanpa tunjangan atau upah pokok termasuk tunjangan tetap yang ditetapkan oleh gubernur tiap tahun berdasarkan $\mathrm{KHL}$ dengan memperhatikan produktifitas dan pertumbuhan ekonomi. Kebijakan pengupahan diarahkan untuk pencapaian penghasilan yang memenuhi penghidupan yang layak bagi Pekerja/Buruh, sehingga mampu memenuhi kebutuhan hidup Pekerja/Buruh dan keluarganya secara wajar (Perpres nomor 78, 2015).

Kemiskinan dipandang sebagai ketidakmampuan dari sisi ekonomi untuk memenuhi kebutuhan dasar makanan dan bukan makanan yang diukur dari sisi pengeluaran. Jadi Penduduk Miskin adalah penduduk yang memiliki rata-rata pengeluaran perkapita perbulan dibawah garis kemiskinan. Garis Kemiskinan (GK) merupakan penjumlahan dari Garis Kemiskinan Makanan (GKM) dan Garis Kemiskinan Non Makanan (GKNM). Penduduk yang memiliki rata-rata pengeluaran perkapita per bulan dibawah Garis Kemiskinan dikategorikan sebagai penduduk miskin. Garis Kemiskinan Makanan (GKM) merupakan nilai pengeluaran kebutuhan minimum makanan yang disetarakan dengan 2100 kilokalori perkapita perhari. Paket komoditi kebutuhan dasar makanan diwakili oleh 52 jenis komoditi (padipadian, umbi-umbian, ikan, daging, telur dan susu, sayuran, kacang-kacangan, buah-buahan, minyak dan lemak, dll). Garis Kemiskinan Non Makanan (GKNM) adalah kebutuhan minimum untuk perumahan, sandang, pendidikan dan kesehatan. Paket komoditi kebutuhan dasar non makanan diwakili oleh 51 jenis komoditi di perkotaan dan 47 jenis komoditi di pedesaan (BPS, 2018).

c) Price Income Ratio (PIR)

Berdasarkan The International Demographia (2006) merumuskan PIR merupakan perbandingan antara median harga rumah dengan median pendapatan rumah tangga dalam satu tahun. Suatu rumah tangga dikatakan tidak terjangkau bila nilai PIR lebih besar dari 3.
Tabel 1 Kategori Keterjangkauan

\begin{tabular}{cc}
\hline $\begin{array}{c}\text { Nilai } \\
\text { Indeks }\end{array}$ & Keterjangkauan \\
\hline$>5$ & $\begin{array}{c}\text { Sangat tidak terjangkau/sangat } \\
\text { tidak mampu } \\
\text { (severely unaffordable) }\end{array}$ \\
\hline $4,1-5,0$ & $\begin{array}{c}\text { Tidak terjangkau/tidak mampu } \\
\text { (seriously unaffordable) }\end{array}$ \\
\hline $3,1-4,0$ & $\begin{array}{c}\text { Hampir tidak terjangkau/hamper } \\
\text { tidak mampu } \\
\text { (moderately unaffordable) }\end{array}$ \\
\hline$\leq 3$ & $\begin{array}{c}\text { Terjangkau/mampu } \\
\text { (Affordable) }\end{array}$ \\
\hline
\end{tabular}

Sumber: The International Demographia (2006). http://www.demogrphia.com

\section{d) Deficit Affordability}

Rumus daya beli atau keterjangkauan penyediaan perumahan berdasarkan Kutty, (2005) rumus deficit affordability $(D)=\mathrm{I}-\mathrm{S}-\mathrm{N}$; $\mathrm{D}=$ Defisit anggaran keluarga/besar subsidi perumahan berdasarkan program berjalan, disetarakan $=0$, perhitungan berdasarkan biaya ditanggung masyarakat setelah subsidi pemerintah; $\mathrm{S}$ = Biaya perumahan (shelter cost), biaya yang ditanggung masyarakat MBR setelah mendapatkan subsidi; dan $\mathrm{N}=$ Biaya non perumahan; I = Pendapatan keluarga/Setara dengan $\mathrm{S}+\mathrm{N}$. Biaya non perumahan didapatkan daristandar hidup minimal berdasarkan daftar $\mathrm{KHL}$ dengan mengeluarkan angka pengadaan rumah, sedangkan angka biaya rumah didapatkan berdasarkan besaran biaya perumahan yang riil dikeluarkan denga beberapa jenis status kepemilikan dikaitkan dengan besar susidi yang diberikan pemerintah untuk MBR.

\section{METODE PENELITIAN}

Data sekunder merupakan data yang digunakan dalam tulisan ini, penyedia data BPS (Garis Kemiskinan) dan Kemenakertrans (Kebutuhan Hidup Layak), dan data primer sebagai studi kasus di ambil di Kota Bandung, untuk mengetahui harga bahan kebutuhan yang perlu dipenuhi untuk mencapai kehidupan layak. sedangkan untuk konsep, definisi dilakukan berdasarkan kajian pustaka dari beberapa regulasi yang telah ada dan buku-buku yang dikeluarkan oleh instansi pemerintah dan pengarang lainnya. Metode analisis deskriptif digunakan dalam penelitian ini, program excel 
digunakan untuk mengolah data di Kota Bandung, berupa data sekunder maupun primer menjadi informasi.

\section{HASIL DAN PEMBAHASAN}

Penentuan batas MBR dilatarbelakangi oleh pemahaman dari teori hierarki kebutuhan maslow bahwa setiap individu mempunyai kebutuhankebutuhan dasar yang digambarkan sebagai sebuah hierarki atau tangga yang menggambarkan tingkat kebutuhan. Terdapat lima tingkat kebutuhan dasar (dari urutan terbawah sampai tertinggi), yaitu:

1) Kebutuhan fisiologis;

2) Kebutuhan akan rasa aman;

3) Kebutuhan akan rasa memiliki dan kasih sayang

4) Kebutuhan akan penghargaan dan;

5) Kebutuhan akan aktualisasi diri.

Maslow memberi hipotesis bahwa setelah individu memuaskan kebutuhan pada tingkat paling bawah, individu akan memuaskan kebutuhan pada tingkat yang berikutnya. Jika pada tingkat tertinggi tetapi kebutuhan dasar tidak terpuaskan, maka individu dapat kembali pada tingkat kebutuhan yang sebelumnya. Kebutuhan akan pangan dan sandang merupaan kebutuhan fisiologis, secara hierarki pemenuhan kebutuhan terhadap pangan merupakan kebutuhan paling dasar setlah itu baru meningkat ke kebutuhan sandang. Pemenuhan kebutuhan terhadap perumahan merupakan pemenuhan kebutuhan terhadap rasa aman, oleh karena itu untuk dapat memenuhi kebutuhan rumah tinggal secara layak, harus terlebih dahulu dapat dipenuhi kebutuhan pangan dan sandang secara layak.

Dalam pembahasan ini akan diuraikan penentuan batas MBR berdasarkan KHL, PIR dan besar angsuran sesuai dengan regulasi yang berlaku sekarang. Angka batas pendapatan MBR yang didapatkan dengan menggunakan PIR dan besar angsuran akan dibandingkan dengan angka batas pendapatan MBR yang didapatkan melalui $\mathrm{KHL}$, dengan demikian dapat dilihat kedua angka batas MBR (dengan PIR dan angsuran) ada pada posisi berapa persen memenuhi kebutuhan hidup layak. Hasil tersebut dapat memberikan gambaran program subsidi pemerintah yang perlu diberikan pada keluarga MBR sehingga mereka dapat memenuhi kebutuhan hidup layak dari segi pangan, sandang (non perumahan) dan perumahan. a) Penentuan batas MBR berdasarkan KHL dan deficit affordability

Batas pendapatan MBR ditetapkan berdasarkan angka range, nilai minimal $\left(4{ }^{*} \mathrm{GK}\right)$ dan nilai maksimal (pengeluaran hidup layak 4 orang anggota keluarga). GK adalah kebtuhan minimal hidup layak, merupakan kebutuhan dasar makanan untuk memenuhi konsumsi 2100 kkal perkapita perhari (diwakili paket komoditi kebutuhan dasar makanan sebanyak 52 jenis), pendapatan di bawah GK dikelompokkan sebagai masyarakat miskin. Pengeluaran keluarga dibagi menjadi dua, yaitu pengeluaran perumahan dan non perumahan (Kutty, 2005). Pengeluaran perumahan keluarga MBR tergantung dari program subsidi perumahan yang dicanangkan pemerintah. Pengeluaran non perumahan didapatkan melalui modifikasi $\mathrm{KHL}$ Kemenakertrans, terdiri dari 7 komponen, item pengadaan tempat tinggal:1. Makanan \& Minuman (11 items); 2. Sandang (13 items); 3. Perumahan (26 items dikurangi 1 item, pengadaan tempat hunian); 4. Pendidikan (2 item); 5. Kesehatan (5 items); 6. Transportasi (1 item); 7. Rekreasi dan Tabungan (2 item).

Modifikasi untuk menghitung $\mathrm{KHL}$ keluarga dari KHL Kemenakertrans adalah penambahan dan pengelompokkan item Komponen, penambahan jumlah komponen serta penambahan kolom bobot dan klasifikasi bobot item, dapat dilihat pada gambar: 


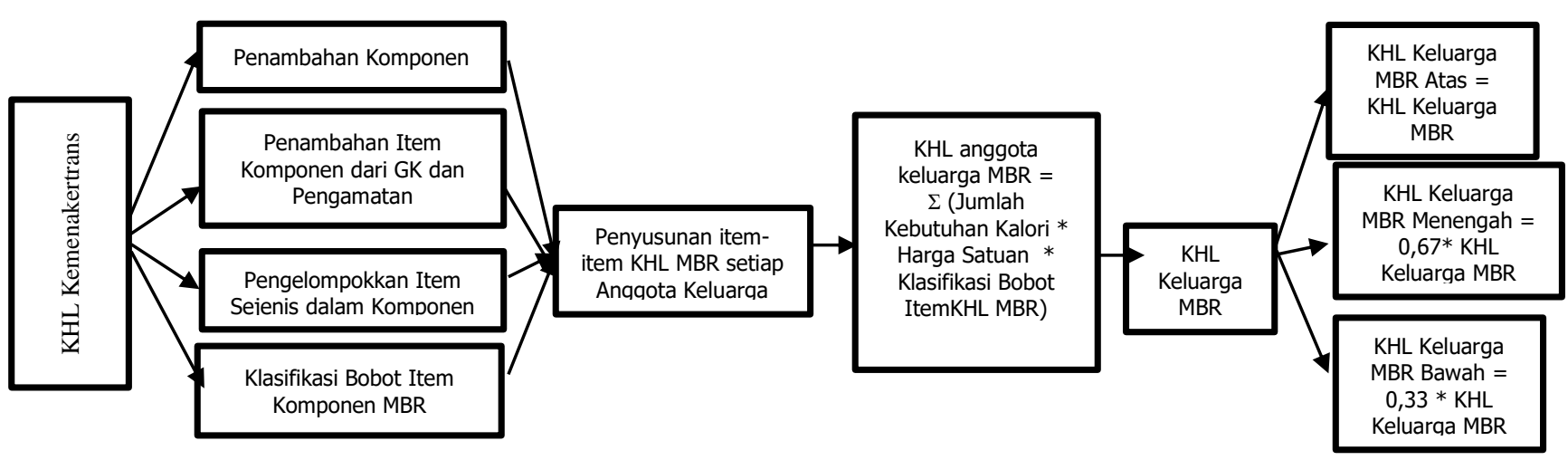

Gambar 1. Modifikasi dan tahapan penghitungan klasifikasi keluarga MBR

- Jumlah komponen menjadi 8, tambahan komponen komunikasi, saat ini komunikasi sudah merupakan basic needs, diperlukan oleh setiap individu. Penambahan item dalam Komponen, sandang 1 item (perlengkapan menjahit); perumahan 5 item ( 2 item dari GK: tas, koper dll dan arloji, jam, kamera, dll; 3 item tambahan baru: pungutan retribusi, kebersihan rumah, dan air limbah); pendidikan 2 item (seragam dan tas sekolah); kesehatan 2 item (suplemen dan obat rutin), untuk item komponen sejenis dilakukan pengelompokkan.

- Item-item setiap komponen dikelompokkan menjadi 3 jenis keberadaan item: 1) setiap anggota keluarga (a. makanan dan minuman; b. pangan, disesuaikan jenisnya dengan jenis kelamin dan posisi anggota keluarga; c. perumahan: perlengkapan makan, sabun cuci, arloji; d. kecantikan: perlengkapan mandi, barang kecantikan, obat anti nyamuk dan suplemen; e. paket data dan komunikasi); 2) salah seorang anggota keluarga (a. sandang, kebutuhan menjahit di item KHL ibu; b. perumahan: perkakas rumah tangga, perlengkapan dapur, koper, PBB, retribusi/air bersih/air limbah/listrik di item KHL bapak; c. kesehatan BPJS di item KHL bapak; $d$. transportasi, pajak kendaraan di item $\mathrm{KHL}$ bapak; rekreasi dan tabungan, tabungan di item KHL bapak); 3) beberapa anggota keluarga (a. perumahan, perlengkapan tidur tidak ada di item KHL ibu, sudah ada di ayah; b. pendidikan, baju seragam dan tas sekolah anak di item anak).

- Penambahan nilai bobot setiap item. Bobot item nilai 1 (kelompok MBR atas) ketika tidak ada modifikasi dari jumlah kebutuhan setiap item KHL Kemenakertrans, minuman, menggunakan Rata-rata kecukupan energi dan protein penduduk Indonesia 2150 kkal/orang (Permenkes RI No. 75 tahun 2013), bobot komponen $2150 / 3000=0,72$, sebagai MBR atas, MBR menegah $=0,66$ * MBR atas, MBR Bawah $=0,33$ * MBR Atas.

\section{b) Penetapan batas pendapatan keluarga MBR}

Visualisasi penetapan batas pendapatan keluarga MBR akan dihitung batas pendapatan keluarga MBR di Kota Bandung. Perhitungan berdasarkan tahapan di atas, dengan memasukan harga item-item di Kota Bandung (didapat dari harga perwakilan supermarket dan pasar tradisional tahun 2017), walaupun belum bisa memenuhi perwakilan harga sampel di Kota Bandung, tapi cukup untuk memberikan gambaran secara kasar.

Tabel 2. Pengeluaran kebutuhan hidup layak 1 bulan

\begin{tabular}{|c|c|c|c|}
\hline \multirow{2}{*}{ Anggota Keluarga } & \multicolumn{3}{|c|}{$\begin{array}{l}\text { Angka Pengeluaran untuk Memenuhi Standar } \\
\text { Kebutuhan Hidup Layak } 1 \text { bulan (satuan rupiah) }\end{array}$} \\
\hline & Atas & Menengah & Bawah \\
\hline Laki-laki Dewasa (Bapak) & 2.075 .769 & 1.556 .827 & 1.037 .885 \\
\hline Perempuan Dewasa (lbu) & 1.300 .558 & 975.418 & 650.279 \\
\hline Anak Laki-laki & 1.088 .874 & 816.665 & 544.437 \\
\hline Anak Perempuan & 921.626 & 911.918 & 614.387 \\
\hline Standar Pendapatan Keluarga MBR & 5.623 .076 & 3.871 .730 & 1.935 .454 \\
\hline
\end{tabular}


Pendapatan keluarga MBR terletak di atas pendapatan keluarga miskin. GK Kota Bandung tahun $2017=\mathrm{Rp}$ 420.579,-- biaya harus dikeluarkan untuk memenuhi kebutuhan minimal hidup layak/bulan/kapita, kebutuhan satu keluarga, adalah 4 × $420.579=\mathrm{Rp} 1.682 .316,-$. Batas pendapatan MBR dikaitkan dengan besaran angka UMK dengan besaran UMK Kota Bandung = Rp. 2.843.663,-dapat dilihat pada gambar di bawah ini.

Biaya perumahan ditentukan berdasarkan program subsidi pemerintah. Harga rumah tapak FLPP berdasarkan Kepmen PUPR No. 552 Tahun 2016 untuk Provinsi Jawa Barat sebesar $\mathrm{Rp}$ 130.000.000, rincian: uang muka $5 \%=\mathrm{Rp}$ 6.500 .000 , tenor 20 tahun, bunga 5\%/tahun, dan cicilan/bulan sebesar Rp 815.045. Harga rumah susun FLPP berdasarkan sebesar Rp 262.800.000,-, dengan rincian: uang muka 5\% = Rp 13.140.000,-, tenor 20 tahun, bunga $5 \% /$ tahun, dan cicilan /bulan sebesar Rp 1.647.645,50,-. Keterjangkauan penyediaan perumahan dengan rumus deficit affordability (D) = I - S - N (Kutty, 2005); D = Defisit anggaran keluarga/besar subsidi perumahan berdasarkan program berjalan, disetarakan $=0$, perhitungan berdasarkan biaya ditanggung masyarakat setelah subsidi pemerintah; I = Pendapatan keluarga/Setara dengan biaya pengeluaran non perumahan dan perumahan berdasarkan program; $\mathrm{S}=$ Biaya perumahan (shelter cost), biaya yang ditanggung masyarakat MBR setelah mendapatkan subsidi; dan $\mathrm{N}=$ Biaya non perumahan (non-shelter cost).

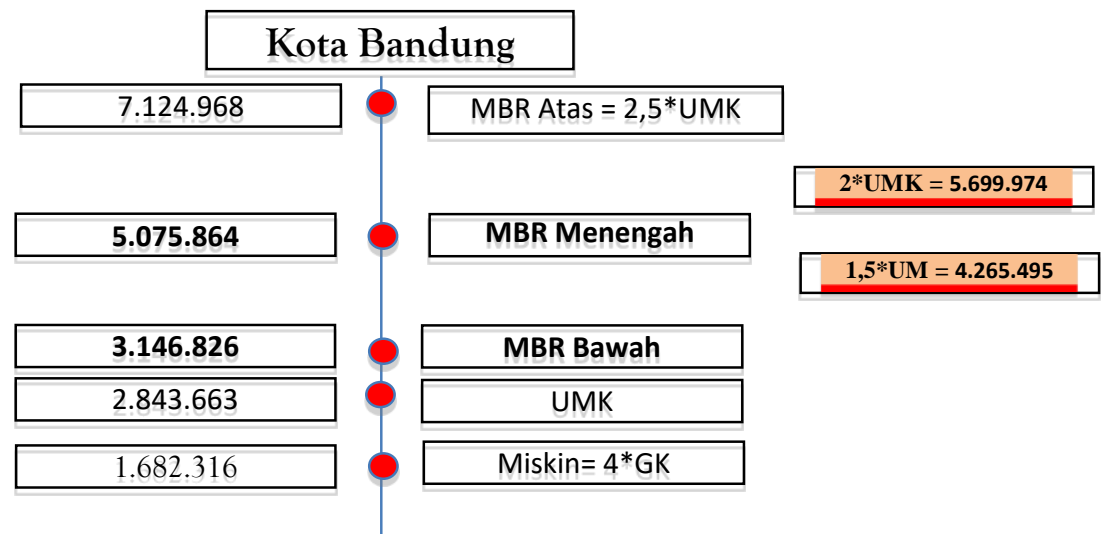

Gambar 2. Perhitungan pendapatan berdasarkan kelas MBR Kota Bandun

Tabel 3. Pengeluaran kebutuhan hidup layak 1 bulan (dalam rupiah)

\begin{tabular}{|c|c|c|c|c|c|}
\hline $\begin{array}{l}\text { Klasifikasi } \\
\text { MBR }\end{array}$ & $\begin{array}{c}\text { Batas Bawah } \\
\text { dan Atas } \\
\text { Pengeluaran } \\
\text { Non } \\
\text { Perumahan } \\
\text { MBR } \\
\text { (N)/bulan } \\
\text { (dalam } \\
\text { rupiah) }\end{array}$ & $\begin{array}{l}\text { Ketera- } \\
\text { nga }\end{array}$ & $\begin{array}{l}\text { Pengeluaran Biaya } \\
\text { Rumah Usulan } \\
\text { Program (S)/bulan } \\
\text { (dalam rupiah) }\end{array}$ & $\begin{array}{l}\text { Batas Pengeluaran Non } \\
\text { Perumahan (N) dan } \\
\text { Perumahan (S) } \\
\text { Keluarga MBR } \\
\text { (dalam rupiah) }\end{array}$ & $\begin{array}{l}\text { Batas Pendapatan MBR/ } \\
\text { Usulan Program } \\
\text { Penyediaan Perumahan }\end{array}$ \\
\hline Bawah & $\begin{array}{c}4^{\star} \mathrm{GK}<\mathrm{x} \leq \\
2.846 .826 \\
1.682 .316<\mathrm{x} \\
\leq 2.846 .826\end{array}$ & $\begin{array}{c}\text { Memenuhi } \\
30,3 \%- \\
50 \% \\
\text { KHL } \\
\text { keluarga }\end{array}$ & $\begin{array}{l}\text { Rumah sewa: } \\
\text { Rusun: } 245-300\end{array}$ & $\begin{array}{l}\text { Rumah Sewa } \\
\text { Rusun: } \mathrm{N}+\mathrm{S}_{\text {sewa Rusun transsit }} \\
\text { tipe } 24 \\
1.927 .316<\mathrm{x} \leq 3.091 .826 \\
\text { Rusun: } \mathrm{N}+\mathrm{S}_{\text {sewa Rusun transsit }} \\
\text { tipe } 27 \\
1.927 .316<\mathrm{x} \leq 3.146 .826\end{array}$ & $\begin{array}{l}\text { Batas pendapatan MBR } \\
4^{\star} G K \leq x \leq 3.146 .826 \\
\text { Usulan Program: Rusun } \\
\text { Sewa } \\
\text { a. Rusun: } N+S_{\text {sewa Rusun transsit }} \\
\text { tipe } 24 \\
\quad 4^{*} G K<x \leq \text { UMK } \\
\text { b. Rusun: } N+S_{\text {sewa Rusun transsit }} \\
\text { tipe } 27 \\
\quad \text { UMK }<x \leq 3.146 .826\end{array}$ \\
\hline Menengah & $\begin{array}{l}2.846 .826,5< \\
x \leq 4.260 .819\end{array}$ & $\begin{array}{c}\text { Memenuhi } \\
50,5 \%- \\
75 \% \\
\text { KHL } \\
\text { keluarga }\end{array}$ & $\begin{array}{l}\text { Rumah sewa: Type } \\
\text { 36 } \\
\text { Rusun: } 245-300 \\
\text { Rumah Milik(cicil) } \\
\text { Tapak: } 815.045 \\
\text { Susun: } 1.647 .645 \\
\text { Subsidi Uang Muka: } \\
\text { Tapak: } 6.500 .000 \\
\text { Susun: } 13.140 .000\end{array}$ & $\begin{array}{l}\text { Rumah Sewa } \\
\text { Rusun: } \mathrm{N}+\mathrm{S}_{\text {sewa Rusun transsit }} \\
\text { tipe } 36 \\
\text { 3.661.872 }<\mathrm{x} \leq 4.494 .472 \\
\text { Rumah Milik } \\
\text { Tapak: } \mathrm{N}+\mathrm{S}_{\text {cicil milik Tapak }} \\
\text { 3.661.872 }<\mathrm{x} \leq 4.494 .472\end{array}$ & $\begin{array}{l}\text { Batas pendapatan MBR } \\
\text { 3.146.826 < } x \leq 5.075 .864 \\
\text { Usulan Program: } \\
\text { 1. Rusun Sewa Pusat Kota: } \\
N+\mathrm{S}_{\text {sewa }} \text { Rusun transsit tipe } 36 \\
\text { 3.146.826 }<\leq 1^{*} 5 \mathrm{UMK} \\
\text { 2. Rumah Milik: } \\
\text { Subsidi: uang muka, cicilan } \\
\text { Rumah Tapak: } \\
\text { 3.146.826 }<\mathrm{x} \leq 1^{*} 5 \mathrm{UMK}\end{array}$ \\
\hline
\end{tabular}




\begin{tabular}{|c|c|c|c|c|c|}
\hline $\begin{array}{l}\text { Klasifikasi } \\
\text { MBR }\end{array}$ & $\begin{array}{c}\text { Batas Bawah } \\
\text { dan Atas } \\
\text { Pengeluaran } \\
\text { Non } \\
\text { Perumahan } \\
\text { MBR } \\
\text { (N)/bulan } \\
\text { (dalam } \\
\text { rupiah) }\end{array}$ & $\begin{array}{c}\text { Ketera- } \\
\text { nga }\end{array}$ & $\begin{array}{l}\text { Pengeluaran Biaya } \\
\text { Rumah Usulan } \\
\text { Program (S)/bulan } \\
\text { (dalam rupiah) }\end{array}$ & $\begin{array}{l}\text { Batas Pengeluaran Non } \\
\text { Perumahan (N) dan } \\
\text { Perumahan (S) } \\
\text { Keluarga MBR } \\
\text { (dalam rupiah) }\end{array}$ & $\begin{array}{l}\text { Batas Pendapatan MBR/ } \\
\text { Usulan Program } \\
\text { Penyediaan Perumahan }\end{array}$ \\
\hline
\end{tabular}

\begin{tabular}{|c|c|c|c|c|c|}
\hline Atas & $\begin{array}{l}4.260 .819,5< \\
x \leq 5.386 .826\end{array}$ & $\begin{array}{c}\text { Memenuhi } \\
75,5 \%- \\
100 \% \\
\mathrm{KHL} \\
\text { keluarga }\end{array}$ & $\begin{array}{l}\text { Rumah Milik(cicil) } \\
\text { Tapak: } 815.045 \\
\text { Susun: } 1.647 .645\end{array}$ & $\begin{array}{l}\text { Rumah Milik } \\
\text { Tapak: } \\
\text { 5.075.865<x } \leq 5.908 .465 \\
\text { Rusun: } \\
6.201 .871<x \leq \mathbf{2 , 5} \text { UMK }= \\
6.201 .871<x \leq \mathbf{7 . 1 2 4 . 9 6 8}\end{array}$ & $\begin{array}{l}\text { Batas pendapatan MBR } \\
5.075 .864<x \leq 2.5^{\star} U M K \\
\text { Usulan Program: Rumah } \\
\text { Milik } \\
\text { Subsidi: cicilan } \\
\text { a. Rumah Tapak: } \\
5.075 .864<x \leq 5.908 .465 \\
\text { b. Rusun } \\
5.908 .465<x \leq 2.5^{\star} \mathrm{UMK}\end{array}$ \\
\hline
\end{tabular}

Menurut Rosa dan Jatnika (2012), faktor umur (umur tahapan karir perumahan), usaha mendapatkan rumah (pendapatan, pengeluaran, tabungan) dan lokasi rumah merupakan 3 faktor utama yang mempengaruhi pemenuhan terhadap kebutuhan rumah. Pengeluaran untuk penyediaan perumahan masyarakat MBR, pada umumnya di bawah $30 \%$. Pernyataan tersebut didukung dengan pernyataan bahwa persentase rata-rata pengeluaran penyediaan perumahan masyarakat MBR di Kecamatan Banyumanik, Kota Semarang, 20\% dari pendapatannya (Putra dan Manaf, 2014). Terjadi peningkatan pendapatan untuk setiap tahapan karir perumahan, peningkatan tahapan terjadi dengan adanya penambahan umur keluarga, sehingga terjadi peningkatan kualitas dalam pemilikan perumahan (Puskim, 2018). Kondisi tersebut memperlihatkan bahwa akan terjadi peningkatan kelas Pendapatan MBR, dari MBR bawah ke MBR atas, atau bahkan ke non MBR sesuai dengan peningkatan kualitas rumah (Tabel 3).

\section{c) Penentuan batas MBR berdasarkan PIR}

PIR merupakan perbandingan antara median harga rumah dengan median pendapatan rumah tangga dalam satu tahun. Pengkategorian pendapatan keluarga MBR berdasarkan nilai indeks yang didapat melalui perhitungan PIR:

1. Nilai indeks $>5$ menggambarkan kelompok keluarga dengan pendapatan sangat tidak terjangkau;

2. Nilai indeks $4,1-5$, menggambarkan kelompok keluarga dengan pendapatan tidak terjangkau;

3. Nilai indeks $3,1-4$, menggambarkan kelompok keluarga dengan pendapatan hampir tidak terjangkau;
4. Nilai indeks $\leq 3$, menggambarkan kelompok keluarga dengan pendapatan terjangkau.

Keputusan Menteri Pekerjaan Umum dan Perumahan Rakyat Nomor 535 tahun 2019, harga jual rumah sejahtera tapak yang diperoleh melalui kredit/pembiayaan pemilikan rumah bersubsidi nuntuk wilayah 1: Jawa (kecuali Jakarta, Bogor, Depok, Tangerang, Bekasi) dan Sumatera (kecuali Kep. Riau, Bangka Belitung, Kepulauan Mentawai) untuk tahun $2019=\mathrm{Rp}$. $140.000 .000,-$, Bila diasumsikan harga jual rumah yang tercantum dalam permen tersebut merupakan harga median rumah MBR.

Indeks PIR = Median harga rumah/median pendapatan dalam 1 tahun

1. Batasan pendapatan keluarga untuk kelompok keluarga sangat tidak mampu

Indeks PIR 130.000.000/pendapatan 1 tahun $>5$

Pendapatan 1 tahun $=130.000 .000 / 5=$ 2.167.000, pendapatan perbulan $=2.167 .000$ Jadi batas atas pendapatan keluarga MBR sangat tidak terjangkau < Rp. 2.167.000,(pembulatan).

2. Batasan pendapatan keluarga untuk kelompok keluarga tidak mampu

Indeks PIR = 140.000.000/pendapatan 1 tahun $=4,1-5$

Pendapatan 1 tahun $=140.000 .000 / 4,1=$ 2.642.000. (pembulatan).

Jadi batas atas pendapatan keluarga MBR tidak mampu:

Rp. 2.167.000,- - Rp 2.642.000,- 
3. Batasan pendapatan keluarga untuk kelompok hampir tidak mampu

Indeks PIR 140.000.000/pendapatan 1 tahun $=3,1-4$

Pendapatan 1 tahun $=140.000 .000 / 4=$ 2.708.000. (pembulatan)

Pendapatan 1 tahun $=140.000 .000 / 3,1=$ 3.495.000. (pembulatan)

Jadi batas atas pendapatan keluarga MBR hamper tidak terjangkau:

Rp. 2.708.000,- - Rp 3.495.000,-

4. Batasan pendapatan keluarga untuk kelompok mampu

Indeks PIR =

140.000.000/pendapatan 1 tahun $>3$

Pendapatan 1 tahun $=140.000 .000 / 3=$ 3.611.000. (pembulatan)

Jadi batas atas pendapatan keluarga mampu $>$ Rp 3.611.000,-

Dengan indeks seperti di atas terdpatbeberapa nilai yangtidak terdapat dalam kelompok, oleh karena batas pendapatan keluarga dimodofikasi menjadi:

1. Pendapatan keluarga MBR sangat tidak mampu <Rp. 2.167.000,-

2. Rp. 2.167.000,- $\leq$ pendapatan keluarga MBR tidak mampu < Rp 2.708.000,-

3. Rp. Rp 2.708.000,- $\leq$ pendapatan keluarga MBR hampir tidak mampu $\leq$ Rp 3.611.000,-

4. Pendapatan keluarga mampu $>\mathrm{Rp}$ 3.611.000,-

Batas atas pendapatan MBR $=\mathrm{Rp} 3.611 .000,-$

d) Penentuan batas pendapatam MBR berdasarkan Peraturan Menteri Pekerjaan
Umum dan Perumahan Rakyat No. 20 tahum 2014.

Batas pendapatan MBR berdasarkan Peraturan Menteri Pekerjaan Umum dan Perumahan Rakyat No. 20 tahum 2014, dikelompokkan dalam 4 kelompok, pembagian tersebut dapat dilihat pada Tabel 4.

Tabel 4. Batas Pendapatan MBR Berdasarkan Permen Pekerjaan Umum dan Perumahan Rakyat

\begin{tabular}{llll}
\hline No. & \multicolumn{1}{c}{$\begin{array}{c}\text { Kelompok } \\
\text { sasaran KPR } \\
\text { Sejahtera }\end{array}$} & $\begin{array}{c}\text { Penghasilan per } \\
\text { Bulan Paling } \\
\text { Banyak }\end{array}$ \\
\hline 1. & $\begin{array}{l}\text { KPR } \\
\text { Tapak }\end{array}$ & Sejahtera & Rp 4.000.000,- \\
\hline 2. & $\begin{array}{l}\text { KPR } \\
\text { Syariah Tapak }\end{array}$ & Sejahtera & Rp 4.000.000,- \\
\hline 3. & $\begin{array}{l}\text { KPR SP Sejahtera } \\
\text { Susun }\end{array}$ & Rp 7.000.000,- \\
\hline 4. & $\begin{array}{l}\text { KPR SP Sejahtera } \\
\text { Syariah Susun }\end{array}$ & Rp 7.000.000,- \\
\hline
\end{tabular}

Sumber: Permen Pekerjaan Umum dan

Perumahan Rakyat No. 20/PRT/M/2014

Rekap batas pendapatan MBR memperlihatkan bahwa batas atas pendapatan MBR dengan menggunakan RIP dan Peraturan Menteri Pekerjaan Umum dan Perumahan Rakyat ada pada rentang pendapatan $\mathrm{mbr}$ menangah (dengan menggunakan metode pendekatan $\mathrm{KHL}$ ). RIP batas atas keluarga mampu ada pada pemenuhan $54,6 \%$ kebutuhan layak dan Peraturan Menteri Pekerjaan Umum dan Perumahan Rakyat ada pada pemenuhan 70,03 $\%$ kebutuhan layak.

Tabel 5. Rekap batas pendapatan MBR berdasarkan 3 pendekatan

\begin{tabular}{|c|c|c|}
\hline \multicolumn{3}{|c|}{ Batas Pendapatan MBR } \\
\hline KHL & PIR & $\begin{array}{l}\text { Peraturan Menteri Pekerjaan Umum dan } \\
\text { Perumahan Rakyat No. } 20 \text { tahun } 2014\end{array}$ \\
\hline $\begin{array}{l}\text { Pendapatan MBR di bagi menjadi } 4 \text { kategori: } \\
\text { 1. Rp. } 1.682 .316,-\leq \text { pendapatan keluarga } \\
\text { MBR bawah } \leq R p 3.146 .826,- \\
\text { 2. Rp. Rp } 3.146 .826,-<\text { pendapatan } \\
\text { keluarga MBR tengah } \leq \text { Rp } 5.073 .864,-- \\
\text { 3. Rp. Rp 5.073.864,- < pendapatan } \\
\text { keluarga MBR tengah } \leq \text { Rp } 7.124 .968,- \\
\text { Diluar masyarakat MBR ada masyarakat } \\
\text { miskin dengan penghasilan di bawah batas } \\
\text { bawah MBR bawah, dan masyarakat } \\
\text { mampu dengan pendapatan di atas batas } \\
\text { atas MBR atas. }\end{array}$ & $\begin{array}{l}\text { Pendapatan MBR di bagi menjadi } 4 \\
\text { kategori: } \\
\text { 1. Pendapatan keluarga MBR } \\
\text { sangat tidak mampu }<\text { Rp. } \\
2.167 .000,- \\
\text { 2. Rp. } 2.167 .000,-\leq \text { pendapatan } \\
\text { keluarga MBR tidak mampu }<\text { Rp } \\
\text { 2.708.000,- } \\
\text { 3. Rp. Rp 2.708.000,- } \leq \text { pendapatan } \\
\text { keluarga MBR hampir tidak } \\
\text { mampu } \leq \text { Rp 3.611.000,-- } \\
\text { 4. Pendapatan keluarga mampu > } \\
\text { Rp } 3.611 .000,-\end{array}$ & $\begin{array}{l}\text { Batas atas pendapatan MBR dibagi dalam } \\
4 \text { kelompok: } \\
\text { 1. KPR sejahtere tapak }=\text { Rp. } 4.000 .000,-- \\
\text { 2. KPR sejahtera Syariah tapak }=\text { Rp. } \\
7.000 .000,- \\
\text { 3. KPR sejahtera rusun }=\text { Rp. } 7.000 .000,- \\
\text { 4. KPR sejahtera syariah rusun Rp. } \\
7.000 .000,-\end{array}$ \\
\hline
\end{tabular}




\section{KESIMPULAN}

Batas pendapatan MBR beradasarkan $\mathrm{KHL}$ nerupakan pendekatan angka yang seharusnya digunakan dalam menentukan batas pendapatan MBR, karena sudah mengakomodir batas minimal kebutuhan pangan, sandang dan perumahan. Batas atas pendapatan keluarga MBR berdasarkan Peraturan Menteri Pekerjaan Umum dan Perumahan Rakyat dengan menambahkan biaya perumahan merupakan cician KPR sejahtera tapak dan KPR sejahtera syariah tapak, angka yang didapatkan mendekati batas pendapatan MBR tengah berdasarkan $\mathrm{KHL}$, sedangkan untuk cicilan KPR sejahtera rusun dan KPR sejahtera syariah rusun ada pada mendekati batas pendapatan MBR atas berdasarkan KHL. Secara umum batas pendapatan MBR yang ditentukan berdasarkan Peraturan Menteri Pekerjaan Umum dan Perumahan Rakyat berada dibawah pendapatan batas pendapatan MBR berdasarkan $\mathrm{KHL}$, sedangkan untuk batas atas pendapatan MBR berdasarkan PIR untuk masyarakat mampu ada di rentang pendapan MBR tengah, di bawah batas atas pendapatan MBR tengah berdasarkan KHL. Masyarakat mampu berdasarkan PIR adalah lebih ke kemampuan dalam memiliki rumah.

Kelebihan dari batas pendapatan MBR berdasarkan $\mathrm{KHL}$ adalah lebih sensetif terhadap perubahan kemampuan daya beli masyarakat, karena angka tersebut dikorelasikan dengan angka KHL dan UMK, akan lebih menggambarkan kondisi ril di lapangan dimana harga rumah dalam satu propinsi pada kenyataanya cukup bervariasi untuk setiap kota/kabupaten. Harga rumah yang berdasarkan Keputusan Menteri Pekerjaan Umum dan Perumahan Rakyat No. 247 tahun 2015 tentang Proporsi Pendanaan Kredit Pembiayaan Pemilikan Rumah Sejahtera dibagi berdasarkan cakupan wilayah propinsi.

Peraturan Menteri Pekerjaan Umum dan Perumahan Rakyat No. 10 tahun 2019 yang berlaku saat ini, variasi harga rumah subsidi bagi MBR hanya dibagi dalam lima (5) variasi harga, hal tersebut perlu dikaji kembali karena kemampuan daya beli bervariasi untuk setiap kota/kabupaten.

\section{UCAPAN TERIMA KASIH}

Data dalam tulisan ini diambil dalam rangka penelitian yang dibiayai oleh DIPA Puslitbang Permukiman Tahun 2018. Penulis mengucapkan terima kasih kepada semua pihak yang telah berkontribusi dalam pelaksanaan kegiatan penelitian tersebut.

\section{DAFTAR PUSTAKA}

Akbar Satio Putra dan Asnawi Manaf (2014). Perencanaan Perumahan bagi Masyarakat Berpenghasilan Rendah di Kecamatan Banyumanik Kota Semarang. JurnalTeknik PWK Volume 3 Nomor 42014. Universitas Dipenegoro;

BPS (2019). Data Sensus Penduduk. Website $B P S$, bps.go.id;

Keputusan Menteri Pekerjaan Umum dan Perumahan Rakyat Nomor 535 tahun 2019 tentang Batasan Harga Jual Rumah Sejahtera Tapak yang Diperoleh melalui Kredit/Pembiayaan Pemilik Rumah Bersubsidi;

Keputusan Menteri Pekerjaan Umum dan Perumahan Rakyat No. 247 tahun 2015 tentang Proporsi Pendanaan Kredit Pembiayaan Pemilikan Rumah Sejahtera

Kutty Nadine (2005). A New Measure of Housing Affordability: Estimasi and Analitycal, Article in Housing Policy Debate 16 (1) 113 - 142. Result. U.S. Departemen of Housing and Urban Development;

M. S. Suhaidab (2011). N. M. Tawil a , N. Hamzaha, A. I. Che-Ania , H. Basria, M.Y. Yuzaineec. Housing Affordability: A Conceptual Overview for House Price Index. 2nd International Building Control Conference 2011 Housing Affordability. Procedia Engineering 20 (346 - 353); Negeri Yogyakarta.

Peraturan Pemerintah Republik Idonesia Nomor 78 tahun 2015 tentang Pengupahan;

Peraturan Menteri Pekerjaan Umum dan Perumahan Rakyat Republik Indonesia Nomor 10 tahun 2019 tentang Kriteria Masyarakat Berpenghasilan Rendah dan Persyaratan Kemudahan Perolehan Rumah bagi Masyarakat Berpenghasilan Rendah;

Puskim (2016). Pengembangan Model Penyediaan dan Pembiayaan Perumahan bagi Masyarakat Berpenghasilan Rendah. Laporan Akhir Kegiatan Penelitian Puskim, Kementerian PUPR;

Puskim (2018). Pengembangan Model Penyediaan dan Pembiayaan Perumahan bagi Masyarakat Berpenghasilan Rendah, Sub Kegiatan Housing Career. Laporan Akhir Kegiatan Penelitian Puskim, Kementerian PUPR;

Putra dan Manaf (2014). Perencanaan Perumahan bagi Masyarakat MBR di Kecamatan Banyumanik Kota Semarang, 
Jurnal Teknik PWK Volume 3 Nomor 4, Fakultas Teknik, Unuversitas Dipenogara;

Rosa Yulinda dan Jatnika Ratna (2012). Faktor Penentu Kebutuhan Rumah, Studi /Kasus Kota Cirebon, Jurnal Permukiman Volume 7 Nomor 2, Pusat Litbang Perumahan dan Permukiman, Badan Litbang Kementerian PUPR;

Rosa Yulinda (2017). Relationship Between LowIncome Communities (MBR) Needs Life Worth (KHL) and the Poverty line, Journal of Human Settlements Volume 9 Nomor 2, Research Institute for Housing and Human Settlements;
Setiadi Harri Ananta (2018). Menaksir Tingkat Keterjangkauan Kelompok MBR terhadap Persyaratan Finansial Minimal Kredit Kepemilikan Rumah Tapak dengan Fasilitas Likuiditas Pembiayaan Perumahan. Jurnal Sosial Ekonomi Pekerjaan Umum Volume 10 Nomor 1. Puskim, Kementerian PUPR;

Warcito (2016). Implementasi Penetapan Peraturan Pemeritah No. 78 Tahun 2015 Tentang Pengupahan, Jurnal Manajemen Volume 7 Nomor 1 (39-53), Universitas 


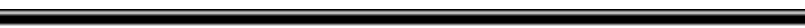

